DOI:

УДК 342.9

\author{
Мар’яна Вербіцька, \\ кандидат юридичних наук, дочент, \\ доиент кафедри конституичійного \\ адміністративного та фінансового права \\ Тернопільського національного \\ економічного університету \\ ORCID: http://orcid.org/0000-0002-5011-7958
}

\title{
Вікторія Ботвинник,
}

студентка юридичного факультету

Тернопільського національного

економічного університету

\section{ЕЛЕКТРОННІ ДОКАЗИ ЯК НОВИЙ ВИД ДОКАЗІВ У АДМІНІСТРАТИВНОМУ СУДОЧИНСТВІ}

Досліджено особливості доказування за допомогою електронних доказів. Особливу увагу приділено характеристиці електронних доказів відповідно до чинного законодавства. Розкрито основні проблеми, пов'язані із розумінням природи та застосуванням електронних доказів у адміністративному судочинстві. Акиентовано увагу на актуальності вказаної теми на сьогодні.

Ключові слова: адміністративне судочинство, докази, електронні докази, доказування, електронний документ, електронний цฺифровий підпис.

Бібл.: 7.

Вербицкая М., Ботвинник В.

Электронные доказательства как новый вид доказательств в административном судопроизводстве

Исследовано особенности доказывания с помощью электронных доказательств. Особое внимание уделяется характеристике электронных доказательств в соответствии с действующим законодательством. Раскрыто основные проблемы, связанные с пониманием природы и применением электронных доказательств в административном судопроизводстве. Акцентируется внимание актуальность указанной темь в настоящее время.

Ключевые слова: административное судопроизводство, доказательства, электронные доказательства, доказывания, электронный документ, электронная ичифровая подпись.

Verbitska M., Botvynnyk $V$.

Electronic evidence as a new type of evidence in administrative judiciary

The article deals with the peculiarities of the evidence by means of electronic evidence. There is a great deal of electronic evidence available today and they are gaining in popularity and proliferation in the institution of evidence, which is an important component of administrative justice. Such popularity is driven by the judicial reform adopted in 2017. This topic has been and is currently being considered by scientists, but it still needs more analysis. In particular, we believe that the most important topic is disclosure: the use of evidence in practice, because there are many problems in proving the use of such evidence. The object of the study is the procedural legal relationship of the proving of the circumstances in specific administrative cases. In particular, using of new types of evidence, so-called electronic evidence, in administrative proceedings.

In the article is revealed the essence of the concept of «electronic evidence», are characterized their features. Examples of evidence, such as, information from websites, correspondence, social networks, etc., sources of their receipt and where they are stored are also considered. The issue of supporting such evidence with an electronic signature is highlighted, which is equally important. And part of the article is devoted to the peculiarities of presenting such evidence to court in administrative cases.

During the course of the scientific research it became clear to us that the rules of the current legislation do not contain clear instructions on the procedure for the use of electronic data in the process of proof, in particular in administrative proceedings. It is also worth emphasized the problems that arise in the process of proof while using electronic evidence. The main issue that needs to be resolved is the clear regulation of the procedure for collecting, filing and presenting such evidence in court, as the study shows that the legislator has identified only general principles

(C) Мар'яна Вербіцька, Вікторія Ботвинник, 2020 
for their application in practice. Also, the recognition of the document as a copy or an original remains unaddressed because it does not have clear criteria for their delineation.

We believe that this topic is quite relevant nowadays and has not been disclosed, and it should be the subject of research by many scientists.

Keywords: administrative proceedings, evidence, electronic evidence, evidence, electronic document, electronic digital signature.

Постановка проблеми. Розвиток науки, техніки та новітніх технологій $є$ вкрай форсованим. Стрімка інформатизація суспільства дає поштовх «йти в ногу» 3 динамікою розвитку новітніх інформаційних технологій як для окремого громадянина, так і для всіх державних інституцій. Судочинство, у тому числі й адміністративне, має відповідати викликам сьогодення, аби максимально забезпечувати захист особи, iii законних прав та інтересів. Таким чином, у результаті запровадження судової реформи та значного оновлення процесуальних кодексів ще в кінці 2017 р. була запроваджена низка новел у процедуру доказування. Одним із таких нововведень стали електронні докази. Їх включення до переліку доказів, за допомогою яких сторони доводять ті обставини, на яких грунтуються їхні вимоги та заперечення, було нагальною потребою, зумовленою судовою практикою.

Проте на сьогодні поняття, природа електронних доказів, процедура їх подання та дослідження все ще недостатньо вивчені на рівні теоретичних досліджень та не цілком зрозумілими для учасників адміністративного процесу. Чинні нормативно-правові акти ще не дають чітких вказівок щодо процедури використання даних, що знаходяться в електронному вигляді, у процесі доказування, тому говорити про ототожнення цієї інформації з доказами ще зарано.

Таким чином, у даній публікації ми проаналізуємо окремі аспекти інституту електронних доказів саме в адміністративному судочинстві.

Аналіз останніх досліджень та публікацій. Тема електронних доказів не $\epsilon$ новою для науки, проте вона не вдосконалена. Свої праці дослідженню електронних доказів присвятили А. Вершиніна, М. Горєлов, В. Колпаков (який розкрив теоретичні основи розуміння поняття «доказування»), А. Каламайко та інші. Проте на сьогодні науковці не знайшли єдиної позиції щодо цього виду доказів, зокрема щодо їх класифікації. Більшість науковців стверджують, що електронними доказами є всі електронні документи, інші доводять, що не всі електронні докази можуть бути документами, оскільки відоме поняття «електронні речові докази». Тому ми вважаємо, що вказана тема потребує детального вивчення і відображення в наукових джерелах.

Мета дослідження - з>ясувати сутність електронних доказів та особливості доказування 3 їх застосуванням в адміністративному судочинстві на підставі юридичної науки, теоретичних засад доказової діяльності та норм чинного законодавства.

Виклад основного матеріалу дослідження. Вагомі зміни до процесуальних кодексів України було прийнято 15 грудня 2017 р. Такі зміни передбачали зміну процесу доказування у судах України. Тому до вже наявних процесуальних кодексів долучили норми, які передбачили використання саме електронних доказів [5, с. 3].

У кожному із трьох процесуальних кодексів України міститься визначення електронних доказів. Якщо їх порівняти, то суттєвої різниці ми не побачимо. Тому такий вид доказів можна охарактеризувати як інформацію, що відображена в електронній формі і дає змогу підтвердити чи спростувати обставини, що стосуються певних справ. Це безпосередньо електронні документи, текстові, голосові й мультимедійні повідомлення, вебсайти, бази даних та інші дані в електронній формі [1, с. 127].

У Кодексі адміністративного судочинства України, зокрема в ст. 99, чітко визначене поняття електронних доказів. Електронними доказами є інформація в електронній (цифровій) формі, що містить дані про обставини, що мають значення для справи, зокрема електронні документи (текстові документи, графічні зображення, плани, фотографії, відео- та звукозаписи тощо), вебсайти (сторінки), текстові, мультимедійні та голосові повідомлення, метадані, бази даних та інші дані в електронній формі. Такі дані найчастіше зберігаються на картах пам'яті чи мобільних телефонах, на серверах чи системах резервного копіювання, а також на інших місцях збереження даних в електронній формі, в тому числі в мережі Інтернет [6, с. 289].

Очевидно, що наявна значна кількість видів електронних доказів, а також джерел інформації, що $є$ невичерпною, оскільки на сьогодні технічний прогрес зумовлює виникнення нових видів електронних доказів.

Відповідно до цього виду доказів можна віднести будь-яку інформацію, що розміщена на вебсайтах, опублікована в соціальних мережах або передана за допомогою месенджерів. Практично кожен користується мережею Інтернет, будь-які дані в будь-який час і в будь-якому місці можна викласти на вебсайтах. Ця інформація може бути як загальнодоступною, так і для обмеженого кола читачів. Але якщо 
Вербіцька М., Ботвинник В.

Електронні докази як новий вид доказів у адміністративному судочинстві

вона буде містити дані, які дають змогу розкрити справу, то їх визнанають, як електронні докази. Сьогодні все більше набувають популярності соціальні мережі і месенджери, за допомогою яких відбувається спілкування, ними користується кожна друга людина. Переписки в месенджерах чи опубліковані пости у соціальних мережах можуть містити дані, у вигляді фото, відео- чи аудіозаписів, а також текстові повідомлення щодо конкретних справ і будуть використані як електронні докази у процесі доказування, звісно, якщо ці докази будуть належними, допустимими, достатніми і достовірними.

Електронні докази відрізняються від інших видів доказів лише тим, що для їх відтворення необхідне використання відповідних технічних засобів. Вони існують в нематеріальному вигляді, їх можна переносити чи копіювати на інші джерела, при цьому не втрачаютьс, їхні основні характеристики. Також вони можуть існувати в декількох місцях одночасно, наприклад, якщо зроблена копія з телефону на інший пристрій, то ідентична інформація буде міститися на двох пристроях.

Якщо подаються електронні докази, сторона має право додати до заяви по суті справи не оригінали, а копії відповідних доказів. Подання таких доказів відбувається через Сдину судову інформаційно-телекомунікаційну систему.

Проаналізувавши судову практику, можемо зазначити, що сьогодні часто виникають питання щодо оформлення, подання та дослідження такого виду доказів, тому що чинне законодавство досі потребує чіткого врегулювання цього питання.

КАС України визначає, що такі докази, як електронні можуть подаватися як в оригіналі, так і в копіях, які обов'язково посвідчуються електронним підписом. Такі докази прикріплюються до матеріалів справи і зберігаються у суді [7, с. 130].

Якщо подається копія доказу, тоді учасник справи повинен вказати про наявність оригіналу в нього або в іншої особи. Крім того, КАС України передбачає, що кожен учасник справи може подати паперовий варіант електронного доказу, в такому випадку такий доказ буде вважатися не письмовим, а саме електронним.

Щоби встановити автора електронного документа, може використовуватися електронний підпис. Електронний підпис - це підпис, який можна отримати шляхом криптографічного перетворення набору електронних даних. Електронний цифровий підпис накладається за допомогою особистого ключа та перевіряється за допомогою відкритого ключа [4, с. 78].

Накладенням електронного підпису завершується створення електронного документа (ч. 2 ст. 6 Закону України «Про електронні документи та електронний документообіг») [3].

Найбільш поширеним сьогодні є листування фізичних осіб, яке здійснюється шляхом використання електронної пошти. Докази у вигляді електронних листів не належать до вищезгаданих документів і тому їх не потрібно посвідчувати електронним цифровим підписом. Також існують електронні докази у вигляді аудіо- або відеозаписів, які також не посвідчуються таким підписом [2].

Чинне законодавство не містить чіткого визначення про те, як повинні збиратися докази в електронній формі, про їх забезпечення, а також про методи їх дослідження, процедури ідентифікації особи, яка відповідальна за розміщення цієї інформації. Вининикає багато непорозумінь щодо використання таких доказів, оскільки законодавець визначив лише загальні принципи їх застосування на практиці.

Так, виникає питання щодо визначення доказу копією чи оригіналом, бо немає визначених критеріїв їх розмежування. Такі докази (як оригінали, так і копії) зазвичай зберігаються або на картах пам'яті, або на дисках, що є сторонніми пристроями. У такому разі електронний документ буде визначатися оригіналом, якщо міститиме обов'язкові реквізити й електронний підпис автора.

Інша складність полягає у встановленні правильної дати і часу оригінального електронного доказу. Чому оригінал? Тому що саме оригінал виступає первинним джерелом і саме за цією ознакою відрізняється від копії, бо копія робиться пізніше, про що обов'язково фіксується датою і часом створення.

Електронні докази, як і інші види доказів, досліджуються безпосередньо судом. У разі необхідності особи, які беруть участь у справі, можуть ознайомлюватися із ними.

Специфічний порядок дослідження цього виду доказів законодавством не визначений. У такому разі застосовують порядок дослідження, призначений для письмових доказів.

Є докази, які неможливо доставити до суду, тоді огляд відбувається за їх місцезнаходженням, про що складається протокол, його підписують усі особи, які беруть участь в огляді.

Висновки. Ми переконані, що застосування електронних доказів в адміністративному процесі є важливою та ефективною складовою процедури доказування. Адже, наприклад, саме вони достовірно і належно підтверджують оголошення на офіційних сайтах органів державної влади, місцевого самоврядування тощо. Хоч про- 
цесуальним законодавством до кінця не врегульовані усі аспекти використання електронних доказів, все ж це є прогресивним і нагальним нововведенням. Проте наразі потрібно достеменно врегулювати процедуру оформлення, подання і дослідження таких доказів, щоб збільшити ефективність їх використання у судових процесах.

\section{Список використаних джерел}

1. Гаран О. В. Спеціальні ознаки електронних доказів у площині когнітивного консонансу. Вісник ОНУ імені I. І. Мечникова. Правознавство. 2019. Т. 24. Вип. 1 (34). С. 125-136.

2. Електронні докази та застосування останніх на практиці. 2018. URL : http://consultant.parus.ua/newszakon?doc=.1DVG08090 (дата звернення: 1.02.2020).

3. Про електронні документи та електронний документообіг : Закон України від 22.05.2003 р. № 851-15. Верховна Рада Украӥни. Офіційний вебпортал. URL : http://zakon0.rada. gov.ua/laws/show/851-15 (дата звернення: 1.02.2020).

4. Найченко А. М. Електронні докази: реалії сьогодення. ДП «Видавничий дім «Персонал». Експерт: парадигми юридичних наук і державного управління. С. 72-85.

5. Про внесення змін до Господарського процесуального кодексу України, Цивільного процесуального кодексу України, Кодексу адміністративного судочинства України та інших законодавчих актів : Закон України від 15.12.2017. Відомості Верховної Ради України. 2017. № 48. Ст. 436.

6. Пунченко А. Я. Електронні засоби доказування в адміністративному процесі. Грані права: XXI століття: матеріали Всеукр наук.-практ конф (19 трав 2018 р.). Одеса : Гельветика, 2018. С. $289-291$.

7. Толкач С. А. Електронні докази як нова категорія адміністративного судочинства: проблеми визначення і правозастосування. Верховенство права очима правників-початківців : матеріали Всеукр. наук. конф. студентів та аспірантів (м. Одеса, 24 листоп. 2018 р.). / за ред. Г. О. Ульянової ; уклад.: Ю. Д. Батан, А. Д. Шкільнюк [та ін.]. Одеса : Гельветика, 2018. С. 129-131.

\section{References}

1. Haran, O. V. (2019). Spetsialni oznaky elektronnykh dokaziv u ploshchyni kohnityvnoho konsonansu [Special features of electronic evidence in the plane of cognitive consonance]. Visnyk ONU imeni I. I. Mechnykova. Pravoznavstvo - Bulletin of ONU named after I. I. Mechnikov, 34, 125-136 [in Ukrainian].

2. Elektronni dokazy ta zastosuvannja ostannikh na praktyci [Electronic evidence and the application of the latter in practice]. (n.d.). consultant.parus.ua. Retrieved from consultant.parus.ua/news-zakon?doc=DVG08090 [in Ukrainian].

3. Zakon Ukrainy «Pro elektronni dokumenty ta elektronnyi dokumentoobih»: pryiniatyi 22 travnia 2003, № 851-15 [Law of Ukraine «On electronic documents and electronic document circulation» from May 22 2003, № 851-15] (2003). Verkhovna Rada Ukrainy, Ofitsiinyi web portal - Verkhovna Rada of Ukraine, The official web portal. Retrieved from http://zakon0.rada. gov.ua/laws/show/851-15 [in Ukrainian].

4. Najchenko, A. M. Elektronni dokazy: realiji sjoghodennja [Electronic Evidence: The Realities of Today]. DP «Vydavnychyi dim «Personal». Ekspert: paradyhmy yurydychnykh nauk i derzhavnoho upravlinnia, $72-85$ [in Ukrainian].

5. Zakon Ukrainy «Pro vnesennia zmin do Hospodarskoho protsesualnoho kodeksu Ukrainy, Tsyvilnoho protsesualnoho kodeksu Ukrainy, Kodeksu administratyvnoho sudochynstva Ukrainy ta inshykh zakonodavchykh aktiv»: pryiniatyi 15.12.2017 [Law of Ukraine «On Amendments to the Economic Procedure Code of Ukraine, the Civil Procedure Code of Ukraine, the Code of Administrative Judiciary of Ukraine, and other legislative acts» from December 15, 2017] (2017). Vidomosti Verkhovnoi Rady Ukrainy - Bulletin of Verkhovna Rada of Ukraine, 48, 436 [in Ukrainian].

6. Punchenko, A. Ya. (2018). Elektronni zasoby dokazuvannia v administratyvnomu protsesi [Electronic means of proof in the administrative process]. Facets of Rights: The 21st Century, Proceedings of the All-Ukrainian Scientific and Practical Conference. Odesa: Helvetika, 289-291 [in Ukrainian].

7. Tolkach, S. A. (2018). Elektronni dokazy yak nova katehoriia administratyvnoho sudochynstva: problem vyznachennia i pravozastosuvannia [Electronic Evidence as a New Category of Administrative Litigation: Problems of Identification and Enforcement]. Verkhovenstvo prava ochyma pravnykiv-pochatkivtsiv: materialy Vseukrainskoi naukovoi konferentsii studentiv ta aspirantiv (m. Odesa, 24 lystopada 2018 r.) - The rule of law through the eyes of beginning lawyers, Materials of the All-Ukrainian scientific conference of students and graduate students (Odesa, November 24, 2018). Odesa: Helvetica, 129-131 [in Ukrainian].

Стаття надійшла до редакції 14.02.2020. 